\title{
Evaluating the efficacy of novel insecticides against Bihar hairy caterpillar, Spilosoma obliqua walker (Lepidoptera: Arctiidae) in soybean crop
}

\author{
S. K. MISHRA*, VIKAS GUPTA AND R.K. SARAF
}

Dryland Horticulture Research and Training Centre, Jawaharlal Nehru Krishi Vishwa Vidyalaya, Garhakota, SAGAR (M.P.) INDIA

\section{ARITCLE INFO}

Received : 24.06 .2017

Revised : 04.08 .2017

Accepted : 18.08 .2017

\section{KEY WORDS :}

Efficacy, Novel insecticides, Spilosoma obliqua

*Corresponding author:

mishradhrtc@gmail.com

\begin{abstract}
A field experiment was conducted at JNKVV, DHRTC farm during 2014 and 2015 to evaluate the effectiveness of eleven insecticides including untreated check against bihar hairy caterpillar, Spilosoma obliqua Walker. All the insecticides were capable of keeping the population of larvae at the minimum level and significant differences were noted among the treatments at 1,2,3 and 7 days after first and second spray of insecticides compared to untreated check. The treatment $\mathrm{T}_{4}$ (Flubendiamide $480 \mathrm{SC}$ ) exhibited its superiority by registering the lowest larval population of 0.80 and 0.15 per meter row length during first and second spray, respectively. The overall order of effectiveness of these insecticides against $S$. obliqua was found to be Flubendiamide $480 \mathrm{SC}>$ Indoxacarb 14.5 SC > Spinosad $45 \mathrm{SC}>$ Thiodicarb $75 \mathrm{WP}>$ Emmamectin benzoate 5 SG > Rynaxypyre 20 SC > Thiomethoxom 25\% WG > Fipronil 5\% SL > Imidacloprid $17.8 \mathrm{SL}>$ Chloropyriphos $20 \mathrm{EC}$. The highest seed yield of $16.88 \mathrm{q} / \mathrm{ha}$. was obtained in the plots treated with Flubendiamide $480 \mathrm{SC}$. The next effective treatments was Indoxacarb 14.5 SC followed by Spinosad 45 SC recorded 14.90 and $14.77 \mathrm{q} / \mathrm{ha}$. The protection efficiency was higher being 88.27 per cent with 11.72 per cent losses in seed yield in Indoxacarb 14.5 SC. Maximum yield loss 43.72 per cent was noticed in untreated crop against 11.72 to 37.79 per cent in different insecticidal treatments.
\end{abstract}

How to view point the article : Mishra, S.K., Gupta, Vikas and Saraf, R.K. (2017). Evaluating the efficacy of novel insecticides against Bihar hairy caterpillar, Spilosoma obliqua walker (Lepidoptera: Arctiidae) in soybean crop. Internat. J. Plant Protec., 10(2) : 241-246, DOI : 10.15740/ HAS/IJPP/10.2/241-246. 